\title{
Correction to: Dimensions and Challenges of Russian Liberalism
}

\author{
Riccardo Mario Cucciolla
}

\section{Correction to:}

\author{
R. M. Cucciolla (ed.), Dimensions and Challenges \\ of Russian Liberalism, Philosophy \\ and Politics - Critical Explorations 8, \\ https://doi.org/10.1007/978-3-030-05784-8
}

Owing to an unfortunate oversight the chapter - "Introduction: The Many Dimensions of Russian Liberalism" - was included as part of the book front matter in the initially published version. It has now been included as Chapter 1 in order to give the author the full credit for his work. The chapter numbers and the pagination of the subsequent chapters have been changed accordingly. 